\title{
Why Teachers Assign Socially Unequal Marks. A Case for Establishing Tertiary Origin Effects in the Model of Primary and Secondary Effects of Educational Research
}

\author{
Helbig Marcel and Morar Tatiana \\ Berlin Social Science Center \\ Berlin, Germany
}

\begin{abstract}
Subjective expected utility theory assumes that educational paths result from the interplay of primary effects - students' cognitive skills - and secondary effects - academic decisions regarding their educational future. We argue that thus far, the assignment of marks has not been accounted for in the scope of Boudon's model of primary and secondary effects. We propose an elaborated model in which psychological traits are included in the concept of primary effects and introduce a further component, tertiary effects, indicating teachers' socially unequal assignment of marks. Empirically, we demonstrate that a specific psychological skill set has moderate influence on students' marks, it does not, however, account for social inequalities in the assignment of marks. Nevertheless, our findings show that social differences in marks can almost entirely be explained by cognitive, psychological and resource-related tertiary effects. Furthermore, there is some evidence that the extent of tertiary effects is associated with the scholastic configuration of educational institutions. Lastly, we observe that teachers unknowingly overvalue children from higher social classes because they deem them more talented, more willing to achieve and better equipped with parental resources than children from lower social classes. A key question for future research is to find reasons for this biased perception.
\end{abstract}

Keywords: social inequality, school mark; primary, secondary and tertiary effects, teacher bias, germany.

\section{Introduction}

Social inequality in educational attainment is strongly influenced by the interplay of primary and secondary effects at the thresholds of educational systems (Boudon, 1974). Empirically, both primary and secondary effects have proven to be more essential than the respective other, varying from study to 
study (Maaz and Nagy, 2010; Neugebauer, 2010). One of the reasons why primary and secondary effects vary in their impact - a phenomenon most notably found at educational transitions - is that primary effects differ in their definition or operationalisation. Boudon (1974: 28f.) defines primary effects of social origin as cultural inequalities in cognitive abilities such as academic achievements, generated in a child's formative years. In the scope of his conceptualisation, Boudon does not specifiy whether academic achievement is represented by academic competencies as is the case in large-scale studies analyzing scholastic performance such as PISA or PIRLS or whether it is rather quantifiable by marks. As a consequence of this lack of clarity, studies define primary effects either as social inequalities in skills development (Maaz and Nagy, 2010) or as differences in marks (perhaps in want of competence tests) (Neugebauer, 2010).

From our point of view, the debate on primary effects puts an accent on social inequalities in the assignment of marks, a phenomenon which cannot be explained in its entirety by academic competences. Described social inequalities in competence and marks are thus far not fully consistent with subjective expected utility theory. Due to varying intellectually stimulating environments students demonstrate socially unequally distributed competences (primary effects). Additionally, at educational transitions to secondary schools, students and their parents make educational decisions regarding the student's academic future (secondary effects). Marks are not entirely compatible with the scope of these educational decisions. Thus, we consider terms such as "secondary marking effects" (Maaz et al., 2011: 53) as limited with regard to their validity. Finally, students' marks cannot simply be referred to as primary effects, as they are a manifestation of more than solely cognitive skills.

Two parties play a role in the assignment of marks: the student, delivering a certain performance, as well as the teacher, marking said performance. In our view, the teacher's socially unequal assessment of a student's performance is frequently prematurely deemed as "unfair". In this context, it is all too often stated that students from socially less privileged families are "marked less favourably despite the same academic performance" (Maaz, et al., 2011: 18) compared with students from higher social classes.

We will now examine, whether the phenomenon of teachers' less favourable marking of children from lower social classes can be explained by interindividually varying psychological characteristics vital to academic success. We define these characteristics as psychological traits, which have often been shown to have a significant positive impact on performance in educational research (albeit to date there is a paucity of studies associating these traits with differences in socioeconomic status). We hypothesize that the concept of primary social origin effects has an overly narrow focus on competency tests and may thus require further theoretical elaboration.

It is well established that competence tests are not the sole determinants of marks: psychological traits such as conscientiousness or willingness to achieve play an essential role as well (Maaz, et al., 2011). If we found that traits found expression in the marks that teachers assign and thus explained social inequalities, the concept of primary effects would have to be elaborated in consequence: described inter-individually varying psychological traits would 
not necessarily be a manifestation of unjust evaluation, but rather would be a distinct and valid criterion in the assignment of marks. If, however, findings showed that students' psychological traits cannot account for significant differences in marks, we would consequently have to expand Boudon's Primary and Secondary Effects Model by the concept of tertiary effects. We define tertiary effects as the socially unequal assignment of marks to students by teaching staff: If socially unequal marking cannot be attributed to and fully explained by inter-individually varying, cognitive or psychological characteristics, it would mean that these differences are neither covered by primary nor secondary effects. We therefore propose the concept of tertiary origin effects, a term coined by German-language authors in recent times (Blossfeld et al., 2015; Esser, 2016; Gresch, 2012).

\section{Theoretical background}

In countries with an early academic tracking system, such as Germany, marks are much more essential for educational success than in countries in which school tracking takes place in later years or where it is foregone altogether. Given the increasingly internationally oriented school research, studies on internationally comparable academic skills have gained importance. In the case of Germany, however, the test performances in reading and mathematics explain a substantially less amount of variance than the respective marks in German and mathematics do (Wilfried Bos et al., 2004: 203). A teachers' school recommendation however, largely determines the school form a child will transition into after primary school. In some German states, marks are the sole criteria for the formation of a recommendation. As can be seen in the debate on the socially unequal assignment of marks, there is some dissent between educational researchers regarding the question where within the framework of primary and secondary effects to locate the observed phenomenon of teachers' socially unequal assignment of marks. Maaz et al. (2011) for instance coined the term "Secondary Marking Effect". Other authors have introduced the concept of tertiary effects, indicating described socially unequal assignment of marks (Esser, 2016; Gresch, 2012). By establishing a further component in Boudon's effects model, researchers aim to explain aspects of social inequality that cannot fully be accounted for by academic skills or educational decisions. Thus, a third actor, the teacher, who may have a prominent role in producing social inequality by assigning marks or making recommendations (tertiary effects) is introduced. Other authors, however, do not approve of this new component (Diehl et al., 2016; Dollmann, 2016), arguing that marks and the teacher's influence are already covered by primary and secondary effects. Seen from this perspective, marks depict academic skills, which in turn have an effect on educational decisions; however, unlike in the case of Maaz et al. (2011) they are ascribed to primary, not secondary effects.

From our point of view, Blossfeld, et al. (2015) successfully elaborated the concept of primary and secondary effects. In their extended model, they start by drawing the important conceptual separation between academically relevant cognitive skills and non-cognitive skills. In the following, we will use the term "psychological traits" for non-cognitive traits. Psychological traits play an important, yet neglected role in marking. Empirical studies for example, have 
shown that the influence of willingness to achieve on marks is equally strong as of academic skills in reading or mathematics (Stubbe and Bos, 2008). Blossfeld, et al. (2015: 148) suggest the incorporation of additional skills that they deem vital to educational attainment: „metacompetencies, self-concept, self-direction, selfregulation, and social competences". Interestingly, these traits are affected by parental education.

It is our belief that the correlation between psychological traits and marks has thus far been neglected in educational research. Also, teachers' socially unequal assignment of marks is generally frowned upon and possibly unjustly considered "unfair". For instance, there is a common conception that teachers will, consciously or unconsciously, mark children from lower social classes less favourably than children from higher social classes. Blossfeld, et al. (2015: 148) offer the following reasons for said biased marking: "(i) Teachers in general attest children from better-educated families more school adequate noncognitive skills [...].Thus, as described by Bourdieu (1973), it seems that more highly educated parents equip their offspring with a better understanding of the school culture and the ability to act within it (cultural capital) as well as with the corresponding dispositions and perceptions (habitus). (ii) Teachers assume that better-educated parents are in general more able to provide support to their children, if necessary. So, they ascribe a higher success probability to these children's future school careers. And (iii) better-educated parents in general exert more pressure on teachers and educational institutions, if this should be necessary."

The fact that teachers overvalue non-cognitive competencies of children from socially privileged families especially gives rise to the question whether psychologically determined primary effects are in fact teachers' subjective evaluations and thus can be regarded as tertiary effects or whether students have measurable, socially unequally distributed psychological traits (and thus, primary effects) that partially account for socially unequal marking (see Figure 1).

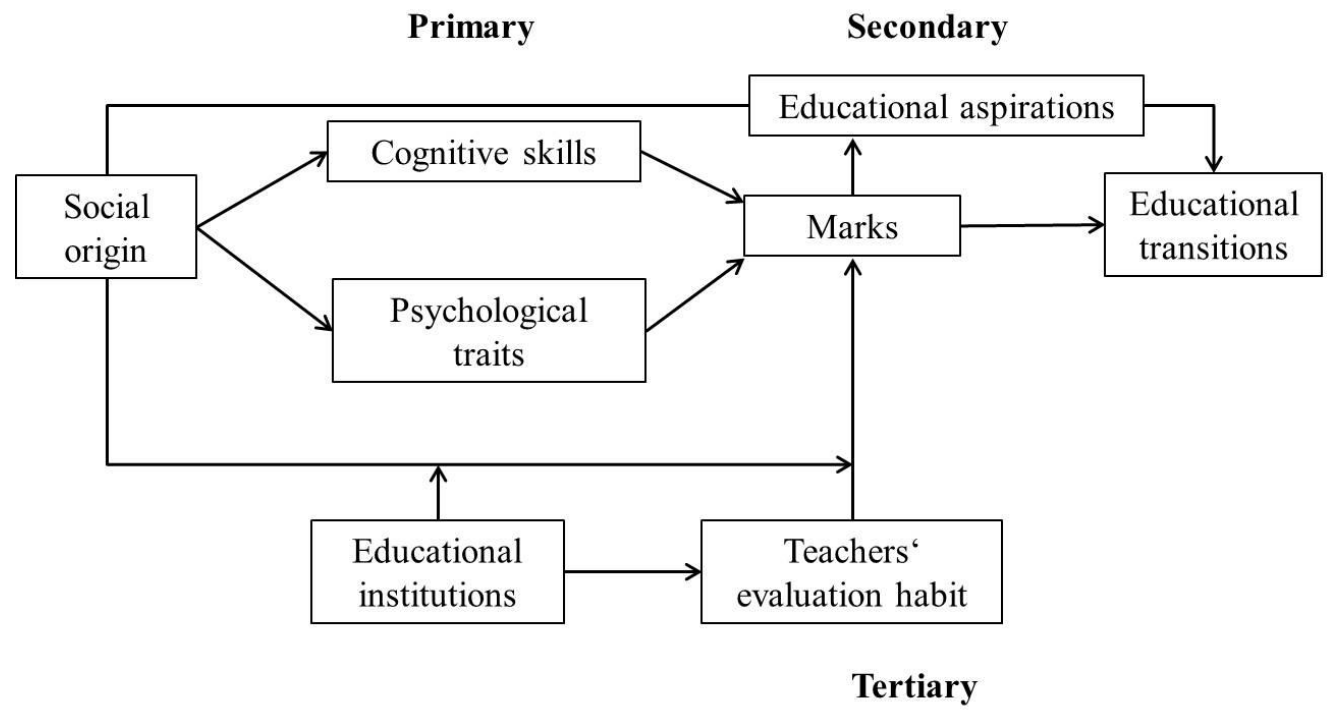

Figure 1. Primary, secondary and tertiary effects at educational transitions. Source: authors' extended illustration based on Blossfeld et al. (2015) 
The focus of our empirical analysis is not to examine the influence of primary and secondary effects on educational transitions. Rather, our aim is to determine whether teachers assign socially "unfair" marks (tertiary effects) or whether teachers' socially unequal evaluations are attributable to students' "objectively" quantifiable psychological traits (primary effects). At first, we will elaborate on the psychological traits that we deem crucial determinants of the socially unequally assignment marks.

\section{Which personality traits have an influence on marks?}

Personality traits - individual differences in behavioural patterns, thoughts and feelings - vary inter-individually, defining a person's character (Cloninger, 1998; Conley, 1984). Behavioural biologists, neuroscientists, psychologists and other social scientists have analysed the development of personality or temperament the developmental precursor of personality - and investigated to what extent personality is genetically versus environmentally shaped. On the assumption that individual personality traits are considered facets of the "Habitus", a person's embodied attitudes, preferences, formal knowledge, behaviour, goods and credentials, that determine the way his or her social world is perceived (Bourdieu, 1987), we hypothesize, that these, too, are influenced by parental socioeconomic status. Which socially unequally distributed personality traits have an influence on marks? In the following, we will focus on the traits locus of control, self-efficacy, conscientiousness, willingness to achieve and the academic self-concept, given that these are socially unequally distributed personality traits that have been proven to be most influential to academic achievement.

Locus of control: Within personality psychology, an individual's locus of control is believed to significantly influence his or her everyday life outcomes. The term was coined originally by Julian Rotter (1966), referring to a person's generalized belief about underlying control or main causes of events in his or her life. A person with a more internal locus of control attributes change to herself and to her action, perceiving herself as an effective agent in controlling the occurrence of positive or negative events. A person with a more external locus of control, by contrast, attributes change to external sources, such as fate, authorities, social constraints or other people in general. A multitude of studies have established a positive correlation between an internal locus of control and marks (Findley and Cooper, 1983; Flouri, 2006; Gifford et al., 2006). One of the few correlational studies examining the influence of socioeconomic status on academic outcomes showed that a higher SES was accompanied by an internal locus of control (Maqsud and Rouhani, 1991).

Self-efficacy: the psychologist and learning theorist Albert Bandura (1997) coined the term "self-efficacy", a psychological trait closely related to the locus of control, which has generated a vast amount of research in social sciences since the 1960s. Self-efficacy refers to a person's belief in their "capabilities to mobilize the motivation, cognitive resources and courses of action needed to exercise control over task demands" (Bandura, 1990: 316). Self-efficacy is determined by two major components - the expectation of competency and the outcome expectancy. A person is more likely to carry out a course of action if a positive outcome is anticipated (outcome expectancy) and if the person judges herself 
capable of successfully performing the course of action with the set of skills she is equipped with (expectation of competency). Self-efficacy, too, has been shown to have a significant positive impact on marks (Multon et al., 1991; Pajares and Johnson, 1994) and it also appears to be socially unequally distributed, such that students from a higher socioeconomic background display a higher degree of self-efficacy (Multon, et al., 1991; Pajares and Johnson, 1994).

Willingness to achieve: a trait highly correlated with self-efficacy and achievement motivation is willingness to achieve, one of the direct outcomes of self-efficacy (Rauer and Schuck, 2003). In the academic context, willingness to achieve is determined by readiness to meet and cope with academic demands notwithstanding possible considerable effort. As was found for the abovementioned psychological traits, Stubbe and Bos (2008) came to the conclusion that an individual's willingness to achieve has a strong positive influence on marks.

Conscientiousness: Conscientiousness, as one of the factors of the Big-Five Personality Inventory is a personality trait "that facilitates task- and goaldirected behaviour such as thinking before acting, delaying gratification, following norms and rules, and planning, organizing and prioritizing tasks" (John et al., 2008, p. 138). (McCrae and Costa, 1994), authors of the more recent Revised NEO-Personality Inventory (NEO-PI-R), considered competence, order, dutifulness, achievement striving, self-discipline and deliberation to be facets of conscientiousness. Empirical evidence has revealed a strong, positive influence of the Big Five personality traits and most commonly of conscientiousness on marks (Maaz, et al., 2011; Poropat, 2009). To date, there is a dearth of studies examining the impact of socioeconomic status on conscientiousness. Some of the few studies, however, have shown that conscientiousness (Jonassaint et al., 2011) and the ability to concentrate (a facet of self-discipline and thus, conscientiousness) are highly correlated with an individual's SES (Kaiser, 2016). Academic self-concept: personal beliefs, past (learning) experiences and selfrelated generalizations constitute a person's self-concept (Rogers et al., 1978). The academic self-concept concerns beliefs related to academic competencies influencing learning behaviour and willingness to achieve (Köller et al., 2006). In search of their performance-related identity, students compare their achievements with others; performance at a given time in each school subject is juxtaposed with a classmate's academic performance (social comparison) or marks achieved in a given subject are compared with marks in another subject (dimensional comparison). As a result, academic self-concept and marks are in constant interdependence (Guay et al., 2003). Regarding the question of correlation between SES and academic self-concept, studies have revealed a social gradient, with the result that a higher SES involves a more positive academic self-concept (Awad, 2007; Marsh, 1984).

In his seminal theory of cultural reproduction, Bourdieu (1987) postulates that cultural capital is transferred from one generation to the next. School systems are biased towards students with certain cultural norms and values, such that those who have acquired cultural capital through their parents are rewarded. Thus, for example, teachers, who often also are members of higher social classes, reward cultural capital - visits to theatres or choice of language - such that it is put on a level with academic skills. Hence, for the assignment of a mark, it may be 
secondary what academic skills the student effectively has. The acquired cultural capital (and thus, associated traits) is a core component of the student's habitus, which in turn mediates the extent of teachers taking notice of a student's strengths and academic achievements. As a result, teachers favour students with a certain habitus which in the long run positively influences their long-term academic performance (Jaeger and Breen, 2016). When marking academic performance, teachers overestimate students with cultural capital because it is considered a sign of academic superiority.

Thus, we can assume that teachers display a biased evaluation of children from higher social classes with a larger quantity of cultural resources, in so far as they deem them more gifted and more willing to achieve than children from lower social classes. The question arises to what extent a socially unequal teacher's assessment is correlated with objective cognitive skills and psychological traits.

Overall, these observations lead to four hypotheses:

H1: The higher the SES of a student, the higher marks they are assigned (with equal skill sets).

H2: Students from higher social classes receive better marks, as they display quantifiable psychological traits positively associated with academic achievement (primary effects).

H3: Students from higher social classes receive higher marks because teachers "subjectively" evaluate their skills as more pronounced and promising compared with children from lower social classes.

One aspect that may deserve special attention in Germany compared with other countries is how teachers assess parental supportive resources: Are parents capable of providing resources vital to their child's success at a challenging secondary school? Albeit these non-academic skills should not be included in teachers' assignment of marks, we hypothesize that mothers of students, especially in Western Germany, where part- time schools and part-time working mothers, who have the time and resources to support their children with homework, tutoring and other school- related endeavors are common phenomena. Described parental support is a crucial determinant for the transition to a secondary school track. We hypothesize that students with a higher socioeconomic background especially benefit from parental support.

H4: Teachers overvalue parental support of their child's future academic career. This biased appraisal is reflected in better marks for students with a higher SES.

The prominent role good marks play in educational decision making differs within German states, such that in some states (e.g. Bavaria) the marks are the sole criterion for teachers' recommendation regarding a secondary school, whereas in Hessia, there are further decision criteria. From a theoretical point of view, the teacher's evaluation of parental resources should not be reflected in marks but rather in the teachers' recommendation for further secondary education. If, however, marks are the sole decision criterion for the recommendation, we hypothesize that the evaluation of parental resources would be reflected more strongly in marks (H4a).

\section{Data and operationalisation}

In the scope of the BiKS Study 8-14 ("educational processes, skills development and selection processes at primary schools") data was gathered by the University 
of Bamberg including students' and teachers' as well as parental assessment of the students' psychological traits. Data collection took place between 2005 and 2014 in Bavarian and Hessian schools in marks three to nine (Artelt et al., 2013). In our study, we utilize data of the third wave (grade 4, second semester), as students are about to transition into a secondary school track. We use some of the data of the first wave too, however, due to partially missing information in the third wave. Moreover, we utilise the German sample from TIMSS 2011 (W. Bos et al., 2015), the Germany-wide IQB-Ländervergleich (Stanat et al., 2014) and the ELEMENT-study from Berlin from the years 2003-2005 (Lehmann, 2008).

In analyzing students' self-assessments of certain psychological traits we explored whether socially unequal marking can be explained by varying psychological traits. Some of the studies gathered further psychological traits potentially relevant for the recommendation, which were not gathered in the scope of the BiKS study. The variables willingness to achieve, locus of control and perseverance were assessed in the context of TIMSS (2011). The IQB gathered additional data on social integration, "school enjoyment" and boredom at school; and finally, ELEMENT additionally assessed the trait "fear of school". We used this data in order to rule out the possibility of other psychological features having an influence on socially unequal marking. In the following, these variables will merely be mentioned, not displayed, as they are not consistent with our theoretical rational, however, they can possibly covary with marks as well as the socioeconomic status.

We defined marks in the subjects German, mathematics and general studies (grade 4, first semester) as the dependent variables. In order that high values correspond with good marks we deemed a recoding of the German marks useful: we recoded them, such that a 1 (highest grade in Germany) was equivalent to a 6 and a 6 (lowest grade in Germany) matched a 1, respectively. Furthermore, we averaged the three subject marks and thus calculated an average grade which is a focal point in our analyses.

We operationalized the concept of social origin as parental education, parental social status and the number of books per household. Cognitive skills were represented by total values of reading and writing competences, abstract reasoning, vocabulary and mathematical skills in grade 4 .

To assess the psychological traits, we used data on students' self-assessment of their willingness to achieve, their academic self-concept and their school motivation, a facet of willingness to achieve (McInerney and Ali, 2006) for each subject respectively. We considered it useful to use the parental assessment of psychological traits for the variables conscientiousness, academic self-concept and willingness to achieve. We used two items for the parental assessment of willingness to achieve, as both did not load on one single factor in the factor analysis. Furthermore, we included the variables work behaviour assessed by the teacher as well as the teachers' evaluations of their students' general talents and parental support. We composed an additive index from various items of the abovementioned variables. The items of these indices had each been analysed in a factor analysis (varimax-rotation) previously. Individual items as well as other control variables such as immigration background, family language, gender, state and year of birth can be found in table A1 in the appendix. 
On a critical note, one limitation is that we were constrained to using self- or parental/teachers' assessment of psychological traits as opposed to a more objective reflection of these skills. To assess these constructs in a strictly psychological (and more objective) sense, one would have to utilize observational methods or elaborated psychometric survey tools. We deemed both less suitable for a quantitative study with more general objectives.

\section{Methods}

We performed multiple imputation (tenfold) on data from wave 1-3 with the statistical software package Stata and more specifically, we performed a multiple imputation by chained equations function named ado's "ice" (Royston, 2004). We only included students with valid times of measurement at the third wave. It should be noted that the BiKS data are of excellent quality with only very few missing values for our variables of interest. Overall, we had recourse to data of 2,032 students in our computations. We conducted a multilevel model analysis with schools representing the higher level. To successfully comparatively evaluate the relative influence of the independent variable on the assignment of marks, we centered all variables (except for the marks) and scaled them to the standard deviation. Consequently, all coefficients could be interpreted as a multiple of standard deviation and are comparable in size.

\section{Results and Discussion}

In the following, we report the average marks in the subjects German, mathematics and general studies only. The results for individual marks can be found in tables A3-A5 in the appendix. At large, all individual marks were consistent with the overall marks. An important difference between the models was that social differences in marks for mathematics and general studies could be fully explained, whereas in marks in the subject German and in overall marks they could not be explained entirely.

As shown in table 1 (M1), the variables parental social status (ISEI-value), parental education as well as books per household had a strong influence on students' marks, with parental education showing the highest influence. The impact of the origin variable dropped by half when cognitive skills (and thus cognitive origin effects) (M2) were controlled for. However, all origin variables still had an effect on the assignment of marks. When psychological traits such as willingness to achieve, the academic self-concept and motivation for specific school subjects were controlled for, we found only marginal changes of the effects of the variables of origin (M3). Moreover, only with a significantly higher amount of motivation in the subjects general studies and mathematics did students achieve better marks. In line with models 1-3 we analysed the other data sets (see operalisation) regarding students' psychological traits (not shown in the following). Even though the psychological traits willingness to achieve, locus of control, perseverance (TIMSS, 2011), social integration as well as school enjoyment (IQB-LV) revealed a positive correlation with marks and boredom at school (IQB-LV) and fear of school (ELEMENT) correlated negatively, respectively, the BiKS data did not significantly contribute to explaining social differences in marking. In analysing data from the TIMSS-study, Maaz et al. (2011) came to the same conclusion regarding the self-assessed variables 
willingness to achieve and conscientiousness. Both constructs positively influenced marks; however, they did not explain social inequalities in marks.

Based on the BiKS data (model 4) we found that parental assessment of their children's psychological traits had a greater contribution in explaining marks compared to the student's self-assessment. Both, the parental assessment of their child's conscientiousness as well as their willingness to achieve positively influenced marks. The parental evaluation of their children's psychological traits did not account for variance in the socially unequal assignment of marks (albeit the social status coefficient slightly decreased in size). The teachers' assessment appeared to be of much greater importance (M5): both the teacher's evaluation of a student's talent and more importantly of a student's work behaviour had a very large contribution in explaining marks. Additionally, the influence of social origin on the assignment of marks decreased substantially; the variables social status and books per household barely reached significance at a 90 percent significance level.

Moreover, the contribution of reading competence, abstract reasoning, vocabulary as well as math skills in explaining marks decreased significantly, albeit it remained statistically significant. Consequently, teachers' also base their assessments of students' talent and work behaviour on the students' cognitive competences.

Yet, the teachers' assessment of talent and work behaviour - as opposed to the parental or student self-assessment - accounted for more social differences in marking. Consequently, teachers evaluated the talents and work behaviour of children with a higher socioeconomic background more favourably compared with children from lower social classes and this evaluation was not consistent with parental and self-assessment. Furthermore, both variables are by a long way the most relevant explanatory factors for marks in grade 4 .

Furthermore, Model 6 showed that students' marks are influenced by the teachers' evaluation of parental support. If parental support was deemed strong, the mark improves on the one hand and a small amount of variance of the socially unequal assignment of marks was accounted for (the influence of the ISEI and the variable books per household became insignificant). It is surprising that this performance-unrelated criterion had such a strong impact on marks (almost as much as talent), as one would not expect any influence until when teachers give a recommendation for a secondary school. Since in Bavaria (as opposed to Hessia), a recommendation for Grammar schools is contingent on a predefined grade point average (Helbig and Nikolai, 2015), it seems obvious that teachers have to assess parental support before they make a school recommendation. And indeed, we found that the teachers' assessment of parental support had a stronger influence on marks in Bavaria than it did in Hessia (M7) ${ }^{1}$. In Hessia, parental support had no significant impact on the marking process.

${ }^{1}$ this is especially the case for the subject general studies, see table 4 in the appendix 
Table 1. Influence of social origin, cognitive skills and psychological traits on grade point average in Grade 4 (linear multilevel model)

\begin{tabular}{|c|c|c|c|c|c|c|c|}
\hline & M1 & M2 & M3 & M4 & M5 & M6 & M7 \\
\hline \multicolumn{8}{|l|}{ Social origin } \\
\hline \multirow[t]{2}{*}{ ISEI } & $0.144^{* *}$ & $0.070^{* *}$ & $0.065^{* *}$ & $0.057^{*}$ & $0.029+$ & 0.022 & 0.020 \\
\hline & $(0.025)$ & $(0.019)$ & $(0.019)$ & $(0.019)$ & $(0.015)$ & $(0.015)$ & $(0.015)$ \\
\hline \multicolumn{4}{|c|}{$\begin{array}{l}\text { Parental education (lower secondary school as } \\
\text { reference) }\end{array}$} & & & & \\
\hline \multirow[t]{2}{*}{ Middle school } & $0.090^{* *}$ & $0.040+$ & $0.040+$ & $0.048+$ & $0.035+$ & $0.033+$ & 0.031 \\
\hline & $(0.028)$ & $(0.020)$ & $(0.020)$ & $(0.021)$ & $(0.017)$ & $(0.017)$ & $(0.017)$ \\
\hline \multirow[t]{2}{*}{ Grammar school } & $0.204^{* *}$ & $0.082^{* *}$ & $0.082^{* *}$ & $0.090^{* *}$ & $0.052^{*}$ & $0.047+$ & $0.046+$ \\
\hline & $(0.031)$ & $(0.023)$ & $(0.022)$ & $(0.023)$ & $(0.020)$ & $(0.020)$ & $(0.020)$ \\
\hline \multirow{2}{*}{$\begin{array}{l}\text { Books per } \\
\text { household }\end{array}$} & $0.100^{* *}$ & $0.046^{*}$ & $0.042+$ & $0.045+$ & $0.031+$ & 0.020 & 0.021 \\
\hline & $(0.027)$ & $(0.020)$ & $(0.019)$ & $(0.021)$ & $(0.017)$ & $(0.018)$ & $(0.018)$ \\
\hline \multicolumn{8}{|l|}{ Test scores } \\
\hline \multirow[t]{2}{*}{ Reading skills } & & $0.107^{* *}$ & $0.110^{* *}$ & $0.101^{* *}$ & $0.050^{*}$ & $0.055^{* *}$ & $0.056^{* *}$ \\
\hline & & $(0.022)$ & $(0.021)$ & $(0.021)$ & $(0.015)$ & $(0.015)$ & $(0.015)$ \\
\hline \multirow[t]{2}{*}{ Spelling skills } & & $0.216^{* *}$ & $0.219^{* *}$ & $0.179^{* *}$ & $0.115^{* *}$ & $0.111^{* *}$ & $0.112^{* *}$ \\
\hline & & $(0.019)$ & $(0.020)$ & $(0.020)$ & $(0.016)$ & $(0.016)$ & $(0.016)$ \\
\hline \multirow[t]{2}{*}{ Vocabulary } & & $0.119^{* *}$ & $0.115^{* *}$ & $0.109^{* *}$ & $0.064^{* *}$ & $0.066^{* *}$ & $0.066^{* *}$ \\
\hline & & $(0.019)$ & $(0.019)$ & $(0.019)$ & $(0.016)$ & $(0.016)$ & $(0.016)$ \\
\hline \multirow[t]{2}{*}{ Math skills } & & $0.244^{* *}$ & $0.213^{* *}$ & $0.184^{* *}$ & $0.096^{* *}$ & $0.094^{* *}$ & $0.094^{* *}$ \\
\hline & & $(0.016)$ & $(0.017)$ & $(0.017)$ & $(0.018)$ & $(0.018)$ & $(0.018)$ \\
\hline \multirow[t]{2}{*}{ Abstract reasoning } & & $0.068^{* *}$ & $0.065^{* *}$ & $0.065^{* *}$ & $0.036^{*}$ & $0.038^{*}$ & $0.039^{*}$ \\
\hline & & $(0.015)$ & $(0.015)$ & $(0.015)$ & $(0.012)$ & $(0.012)$ & $(0.012)$ \\
\hline \multicolumn{8}{|c|}{ Student's self-evaluation } \\
\hline \multirow{2}{*}{$\begin{array}{l}\text { Academic self- } \\
\text { concept }\end{array}$} & & & 0.027 & 0.019 & -0.011 & -0.010 & -0.009 \\
\hline & & & $(0.026)$ & $(0.025)$ & $(0.023)$ & $(0.023)$ & $(0.023)$ \\
\hline \multirow[t]{2}{*}{$\begin{array}{l}\text { Willingness to } \\
\text { achieve }\end{array}$} & & & -0.004 & 0.016 & -0.001 & 0.003 & 0.005 \\
\hline & & & $(0.025)$ & $(0.025)$ & $(0.021)$ & $(0.020)$ & $(0.020)$ \\
\hline \multirow{2}{*}{$\begin{array}{l}\text { Motivation in } \\
\text { subject general } \\
\text { studies }\end{array}$} & & & $0.055^{* *}$ & $0.049^{* *}$ & $0.035^{*}$ & $0.032^{*}$ & $0.031^{*}$ \\
\hline & & & $(0.015)$ & $(0.015)$ & $(0.012)$ & $(0.012)$ & $(0.012)$ \\
\hline \multirow{2}{*}{$\begin{array}{l}\text { Motivation in } \\
\text { subject German }\end{array}$} & & & -0.007 & -0.017 & -0.008 & -0.011 & -0.011 \\
\hline & & & $(0.016)$ & $(0.016)$ & $(0.013)$ & $(0.014)$ & $(0.013)$ \\
\hline \multirow{2}{*}{$\begin{array}{l}\text { Motivation in } \\
\text { subject math }\end{array}$} & & & $0.057^{* *}$ & $0.045^{* *}$ & $0.025^{*}$ & $0.027^{*}$ & $0.027^{*}$ \\
\hline & & & $(0.013)$ & $(0.013)$ & $(0.011)$ & $(0.011)$ & $(0.011)$ \\
\hline \multicolumn{8}{|l|}{ Parental assessment } \\
\hline \multirow[t]{2}{*}{ Conscientiousness } & & & & $0.073^{* *}$ & $0.038^{*}$ & $0.031^{*}$ & $0.031+$ \\
\hline & & & & $(0.019)$ & $(0.013)$ & $(0.013)$ & $(0.013)$ \\
\hline \multirow{2}{*}{$\begin{array}{l}\text { Academic self- } \\
\text { concept }\end{array}$} & & & & $0.049+$ & 0.023 & 0.016 & 0.016 \\
\hline & & & & $(0.023)$ & $(0.016)$ & $(0.016)$ & $(0.015)$ \\
\hline \multirow{2}{*}{$\begin{array}{l}\text { Willingness to } \\
\text { achieve } 1\end{array}$} & & & & $0.084^{* *}$ & $0.052^{*}$ & $0.055^{* *}$ & $0.055^{* *}$ \\
\hline & & & & $(0.017)$ & $(0.015)$ & $(0.015)$ & $(0.015)$ \\
\hline \multirow{2}{*}{$\begin{array}{l}\text { Willingness to } \\
\text { achieve } 2\end{array}$} & & & & $0.049^{*}$ & 0.015 & 0.017 & 0.016 \\
\hline & & & & $(0.019)$ & $(0.014)$ & $(0.014)$ & $(0.014)$ \\
\hline Teachers' assess & & & & & & & \\
\hline Talent & & & & & $0.235^{* *}$ & $0.206^{* *}$ & $0.204^{* *}$ \\
\hline & & & & & $(0.044)$ & $(0.040)$ & $(0.041)$ \\
\hline
\end{tabular}




\begin{tabular}{|l|l|l|l|l|l|l|l|}
\hline Work behaviour & & & & & $\mathbf{0 . 4 0 4}^{* *}$ & $\mathbf{0 . 3 3}^{* *}$ & $\mathbf{0 . 3 9 3 ^ { * * }}$ \\
\hline Parental support & & & & & $(0.109)$ & $(0.112)$ & $(0.112)$ \\
\hline & & & & & & $\mathbf{0 . 0 9 2}^{*}$ & 0.063 \\
\hline $\begin{array}{l}\text { Interaction parental } \\
\text { support x federal } \\
\text { state }\end{array}$ & & & & & & $(0.032)$ & $(0.034)$ \\
\cline { 2 - 8 } & & & & & & & $\mathbf{0 . 0 5 3 +}$ \\
\hline $\begin{array}{l}\text { Federal state of } \\
\text { Bavaria (Hessia } \\
\text { reference) }\end{array}$ & -0.033 & $\mathbf{- 0 . 2 3 1 +}$ & $\mathbf{- 0 . 2 1 5 +}$ & -0.200 & -0.107 & -0.096 & -0.102 \\
\hline & $(0.113)$ & $(0.114)$ & $(0.113)$ & $(0.112)$ & $(0.067)$ & $(0.067)$ & $(0.067)$ \\
\hline Intercept & & & & & & & \\
\hline & 4.455 & 4.582 & 4.165 & 4.248 & 4.280 & 4.289 & 4.297 \\
\hline $\begin{array}{l}\text { Variance school } \\
\text { level }\end{array}$ & $(0.058)$ & $(0.065)$ & $(0.112)$ & $(0.109)$ & $(0.082)$ & $(0.080)$ & $(0.080)$ \\
\hline & 0.053 & 0.097 & 0.094 & 0.080 & 0.038 & 0.036 & 0.035 \\
\hline $\begin{array}{l}\text { Variance } \\
\text { individual level }\end{array}$ & $(0.380)$ & $(0.237)$ & $(0.238)$ & $(0.264)$ & $(0.179)$ & $(0.192)$ & $(0.193)$ \\
\hline & 0.522 & 0.275 & 0.266 & 0.247 & 0.166 & 0.162 & 0.162 \\
\hline Sample size & $(0.031)$ & $(0.052)$ & $(0.053)$ & $(0.057)$ & $(0.036)$ & $(0.038)$ & $(0.038)$ \\
\hline
\end{tabular}

Overall, our results offered evidence that existing social differences in marks (M3) are almost entirely explained by teachers' assessment of a the student's talent and work behaviour as well as their evaluation of parental support (M6). After controlling for said evaluations, parental SES and books per household had no more influence on the mark, while the impact of parental education decreased significantly and was observable at 90-percent significance level only. Both parental and students' self-assessment of psychological traits did not account for teachers' socially unequal assignment of marks.

\section{Conclusion}

In the scope of our study, we analysed to what extent students' psychological traits (an elaboration of the concept of primary effects) account for social inequalities in marking. Additionally, we examined whether evidence would suggest the theoretical introduction of the concept of tertiary effects, to better explain teachers' evaluations. As was also shown in a multitude of studies, we found that with the same cognitive skills, students from lower social classes are given lower marks than their socially more advantaged classmates (H1). Secondly, we observed that psychological traits (assessed by parents or students) have an influence on the teachers' marking; they did not, however, impact the difference between social classes (contrary to H2). Therefore, we did not find evidence for a theoretical elaboration of the concept of primary effects by adding the psychological traits as a further component. The psychological traits we chose for our analysis, which had already been used by other researchers (except for BiKS), did indeed have an influence on marks; however we neither found an influence of parental nor students' self-assessment of psychological traits on teachers' socially unequal assignment of marks.

The teachers' subjective evaluations proved to have a much more substantial impact on marks than the parental or students' assessment of their talent 
(cognitive tertiary effects), work behaviour (psychological tertiary effects) and parental support (resource -related tertiary effects) did: Described evaluations accounted for a significant amount of variance in the marks. Thus, we confirm our third and fourth hypothesis. Moreover, we could show that the influence of parental support on marks was higher in German states in which the school recommendation is contingent on a predefined grade point average (H4a). Thus, both types school recommendation (based on either objective criteria such as marks or more subjective criteria such as teachers' evaluations) contribute to the maintenance of social inequalities in the assignment of marks.

Our findings suggest that changing institutional regulations in schools does not necessarily lead to changes in academic success, as long as institutional regulations can be circumvented by the parties involved (i.e. the teachers). Whether the relationship between parents and teachers, not to mention parental pressure on the teachers, influences marking in federal states where school recommendations are not determined by the grade point average, is a question yet to be resolved. Also, the question remains whether the teachers' evaluation of parental support has less influence in states in which the school recommendation is not contingent on academic achievements compared with states where the recommendation formation is more formal.

A further question arising from our findings is why in general teachers make a socially unequal evaluation of cognitive skills and psychological traits that is in contrast with both students' actual academic competences (measured by school subject-specific tests) and parental/ students' self-assessment? Is their unequal evaluation attributable to habitual differences in students that cause teachers to misjudge certain cognitive and psychological potentials? Contrary to other studies, we find that socially unequal marking is not a deliberate choice. Rather, we believe that teachers regard students from higher socioeconomic backgrounds as more talented and ambitious. A further reason for socially unequally distributed marks is that the teachers assume that children from lower social classes receive less parental support. This criterion is unrelated to academic outcomes and should not play a role in the assignment of marks; however, once again our findings show that teachers, rightly or wrongly, consider parental resources to be decisive in shaping their child's further education.

In accordance with our findings we need to make considerable adjustments to our model in Figure 1 (see Figure 2). Evidently, students' psychological traits play a more secondary role in explaining social inequalities in the assignment of marks. The teachers' subjective evaluations of their students' talents and psychological traits appear to be much more decisive. We believe that the concept of tertiary effects, entailing these performance- unrelated evaluations, should be established, given that the sole focus on primary and secondary effects does not reflect empirical reality. Moreover, it overlooks the teachers' prominent role in producing social inequalities. Thus, for future research, it is of vital importance to closely examine teachers' rational for assigning socially unequal marks.

By the same token, by focusing exclusively on primary and secondary effects it is neglected that teachers' assignment of marks is in turn influenced by educational institutions. A teacher can be considered an agent of the school 
system who determines the extent of social inequality through his/her decision. To date, this finding has been disregarded by the Primary and Secondary effects model, even though some studies have come to similar conclusions regarding the role of school systems in causing (Lindner, 2003; Jähnen and Helbig, 2015). Finally, it is to be noted that the assignment of marks is an influential factor that generates social inequalities in each school system, not only in those with an early academic tracking system. For all federal states in which teachers assign marks as opposed to a more standardized and objective method of competence test, the marks a student receives are decisive for his or her future educational path as well as the long-term academic success.

For instance, empirical findings show that students with a distinguished higher education entrance qualification pursue a university degree significantly more frequently compared with students with lower marks (Helbig, Jähnen and Marczuk, 2015). Consequently, the assignment of marks in non-tracking school systems also may give rise to social inequality in post-secondary education.

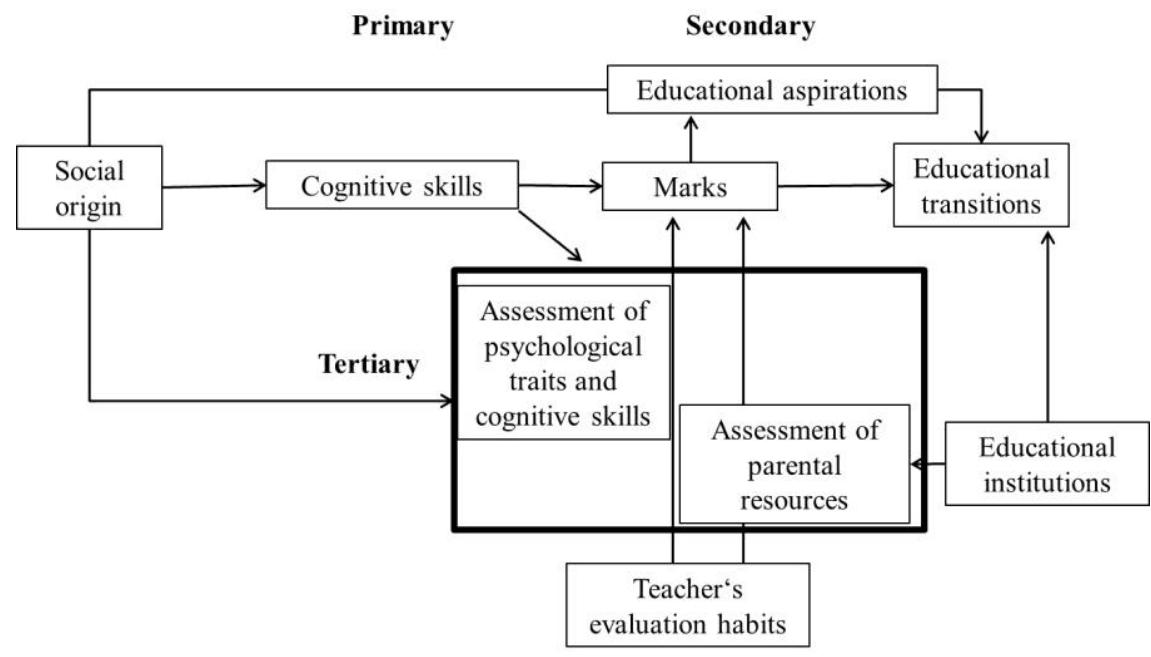

Figure 2. Primary, secondary and tertiary effects explaining social inequality at educational transitions

\section{References}

Artelt, C., Blossfeld, H.-P., Faust, G., Roßbach, H.-G., \& Sabine, W. (2013). Bildungsprozesse, Kompetenzentwicklung und Selektionsentscheidungen im Vorschulund Schulalter (BiKS-8-14). Version 1. [Data set]. Retrieved

Awad, G. H. (2007). The role of racial identity, academic self-concept, and self-esteem in the prediction of academic outcomes for African American students. Journal of Black Psychology, 33(2), pp. 188-207. doi:10.1177/0095798407299513

Blossfeld, P. N., Blossfeld, G. J., \& Blossfeld, H.-P. (2015). Educational Expansion and Inequalities in Educational Opportunity: Long-Term Changes for East and West Germany. European Sociological Review, 31(2), pp. 144-160. doi:10.1093/esr/jcv017

Bos, W., Voss, A., Lankes, E.-M., Schwippert, K., Thiel, O., \& Valtin, R. (2004). Schullaufbahnempfehlungen von Lehrkräften für Kinder am Ende der vierten Jahrgangsstufe. In W. Bos, E.-M. Lankes, M. Prenzel, K. Schwippert, R. Valtin \& G. Walther (Eds.), IGLU Einige Länder der Bundesrepublik Deutschland im nationalen und internationalen Vergleich (pp. 191 - 220). Münster: Waxmann.

Bos, W., Wendt, H., Köller, O., \& Selter, C. (2015). Trends in International Mathematics and Science Study 2011 [Data set]. Retrieved 
Boudon, R. (1974). Education, opportunity, and social inequality: Changing prospects in Western society New York, NY: Wiley.

Bourdieu, P. (1973). Kulturelle Reproduktion und soziale Reproduktion. In P. Bourdieu (Ed.), Grundlagen einer Theorie der symbolischen Gewalt (pp. 88-137). Frankfurt am Main: Suhrkamp.

Bourdieu, P. (1987). Die feinen Unterschiede. Kritik der gesellschaftlichen Urteilskraft Frankfurt am Main: Suhrkamp.

Cloninger, C. R. (1998). The genetics and psychobiology of the tertiaseven-factor model of personality.

Conley, J. J. (1984). The hierarchy of consistency: A review and model of longitudinal findings on adult individual differences in intelligence, personality and self opinion. Personality and Individual Differences, 5(1), pp. 11-25. doi:10.1016/01918869(84)90133-8

Diehl, C., Hunkler, C., \& Kristen, C. (2016). Ethnische Ungleichheiten im Bildungsverlauf: Mechanismen, Befunde, Debatten Wiesbaden: Springer. doi:10.1007/978-3-658$04322-3$

Dollmann, J. (2016). Ethnische Ungleichheiten im Bildungsverlauf: Mechanismen, Befunde, Debatten. In C. Diehl, C. Hunkler \& C. Kristen (Eds.), Ethnische Ungleichheiten im Bildungsverlauf (pp. 517-542). Wiesbaden: Springer

Esser, H. (2016). Bildungssysteme und ethnische Bildungsungleichheit. In C. H. Claudia Diehl, Cornelia Kristen (Ed.), Ethnische Ungleichheiten im Bildungsverlauf: Mechanismen, Befunde, Debatten (pp. 331-396). Wiesbaden: Springer VS. doi:10.1007/978-3-658-04322-3_8

Findley, M. J., \& Cooper, H. M. (1983). Locus of control and academic achievement: a literature review. Journal of Personality and Social Psychology, 44(2), p 419. doi:10.1037/0022-3514.44.2.419

Flouri, E. (2006). Parental interest in children's education, children's self- esteem and locus of control, and later educational attainment: Twenty- six year follow- up of the 1970 British Birth Cohort. British Journal of Educational Psychology, 76(1), pp. 41-55.

Gifford, D. D., Briceno-Perriott, J., \& Mianzo, F. (2006). Locus of Control: Academic Achievement and Retention in a Sample of University First-Year Students. Journal of College Admission, 191(18-25)

Gresch, C. (2012). Der Übergang in die Sekundarstufe I: Leistungsbeurteilung, Bildungsaspiration und rechtlicher Kontext bei Kindern mit Migrationshintergrund Wiesbaden: Springer VS. doi:10.1007/978-3-531-18660-3_11

Guay, F., Marsh, H. W., \& Boivin, M. (2003). Academic self-concept and academic achievement: Developmental perspectives on their causal ordering. Journal of Educational Psychology, 95(1), p 124. doi:10.1037/0022-0663.95.1.124

Helbig, M., \& Nikolai, R. (2015). Die Unvergleichbaren. Der Wandel der Schulsysteme in den 16 deutschen Bundesländern seit 1949 Bad Heilbrunn: Klinkhardt.

Jaeger, M. M., \& Breen, R. (2016). A dynamic model of cultural reproduction. American Journal of Sociology, 121 (4), pp. 1079-1115 doi:10.1086/684012

John, O. P., Naumann, L. P., \& Soto, C. J. (2008). Paradigm shift to the integrative big five trait taxonomy. Handbook of personality: Theory and research, 3, pp. 114-158.

Jonassaint, C. R., Siegler, I. C., Barefoot, J. C., Edwards, C. L., \& Williams, R. B. (2011). Low life course socioeconomic status (SES) is associated with negative NEO PI-R personality patterns. International journal of behavioral medicine, 18(1), pp. 13-21. doi:10.1007/s12529-009-9069-x

Kaiser, T. (2016). Socioeconomic status, parenting and conscientiousness: the unequal devel-opment of children's focus. Journal of Family Studies, pp. 1-24.

Köller, O., Trautwein, U., Lüdtke, O., \& Baumert, J. (2006). Zum Zusammenspiel von schulischer Leistung, Selbstkonzept und Interesse in der gymnasialen Oberstufe. 
Zeitschrift für Pädagogische Psychologie, 20(1/2), pp. 27-39. doi:10.1024/10100652.20.12.27

Lehmann, R. (2008). Erhebung zum Lese- und Mathematikverständnis: Entwicklung in den Jahrgangsstufen 4 bis 6 in Berlin. [Data set]. Retrieved

Maaz, K., Baeriswyl, F., \& Trautwein, U. (2011). Herkunft zensiert? Leistungsdiagnostik und soziale Ungleichheiten in der Schule. Eine Studie im Auftrag der Vodafone Stiftung Deutschland. doi:10.1007/978-3-531-19393-9_13

Maaz, K., \& Nagy, G. (2010). Der Übergang von der Grundschule in die weiterführenden Schulen des Sekundarschulsystems: Definition, Spezifikation und Quantifizierung primärer und sekundärer Herkunftseffekte. In K. Maaz, J. Baumert, C. Gresch \& N. McElvany (Eds.), Der Übergang von der Grundschule in die weiterführende Schule - Leistungsgerechtigkeit und regionale, soziale und ethnischkulturelle Disparitäten (pp. 153-182). Berlin: Bundesministerium für Bildung und Forschung. doi:10.1007/978-3-531-92216-4_7

Maqsud, M., \& Rouhani, S. (1991). Relationships between socioeconomic status, locus of control, self-concept, and academic achievement of Batswana adolescents. Journal of Youth and Adolescence, 20(1), pp. 107-114. doi:10.1007/bf01537354

Marsh, H. W. (1984). Self-Concept: The Application of a Frame of Reference Model to Explain Paradoxical Results. Australian Journal of Education, 28(2), pp. 165-181. doi:10.1177/000494418402800207

McCrae, R. R., \& Costa, P. T. (1994). The stability of personality: Observations and evaluations. Current Directions in Psychological Science, 3(6), pp. 173-175. doi:10.1111/1467-8721.ep10770693

McInerney, D. M., \& Ali, J. (2006). Multidimensional and hierarchical assessment of school motivation: Cross-cultural validation. Educational Psychology, 26, pp. 595612. doi:10.1080/01443410500342559

Multon, K. D., Brown, S. D., \& Lent, R. W. (1991). Relation of self-efficacy beliefs to academic outcomes: A meta-analytic investigation. Journal of counseling psychology, 38(1), p 30. doi:10.1037/0022-0167.38.1.30

Neugebauer, M. (2010). Bildungsungleichheit und Grundschulempfehlung beim Übergang auf das Gymnasium: Eine Dekomposition primärer und sekundärer Herkunftseffekte. Zeitschrift für Soziologie, 39(3), pp. 202-214. doi:10.1515/zfsoz2010-0303

Pajares, F., \& Johnson, M. J. (1994). Confidence and competence in writing: The role of self-efficacy, outcome expectancy, and apprehension. Research in the Teaching of English, pp. 313-331.

Poropat, A. E. (2009). A meta-analysis of the five-factor model of personality and academic performance. Psychological Bulletin, 135(2), p 322. doi:10.1037/a0014996

Rauer, W., \& Schuck, K. D. (2003). FEESS 3-4. Fragebogen zur Erfassung emotionaler und sozialer Schulerfahrungen von Grundschulkindern dritter und vierter Klassen. Göttingen: Beltz.

Rogers, C. M., Smith, M. D., \& Coleman, J. M. (1978). Social comparison in the classroom: the relationship between academic achievement and self-concept. Journal of educational psychology, 70(1), pp. 50-57. doi:10.1037/0022-0663.70.1.50

Royston, P. (2004). Multiple imputation of missing values. Stata Journal, 4(3), pp. 227-241.

Stanat, P., Pant, H. A., Böhme, K., Richter, D., Weirich, S., Haag, N., . . Reimers, H. (2014). IQB Ländervergleich Primarstufe 2011 (IQB-LV 2011) [Data set]. Retrieved

Stubbe, T. C., \& Bos, W. (2008). Schullaufbahnempfehlungen von Lehrkräften und Schullaufbahnentscheidungen von Eltern am Ende der vierten Jahrgangsstufe. Empirische Pädagogik, 22(1), pp. 49-63. 


\section{Appendix}

Table A 1: Operationalisation und distribution of variables

\begin{tabular}{|c|c|c|c|c|c|}
\hline Construct & Operationalisation & $\begin{array}{l}\text { Min- } \\
\text { imum }\end{array}$ & $\begin{array}{l}\text { Max- } \\
\text { imum }\end{array}$ & $\begin{array}{l}\text { Average/ } \\
\text { ratio }\end{array}$ & SD \\
\hline \multicolumn{6}{|l|}{ Marks } \\
\hline Overall mark & $\begin{array}{l}\text { Average of German, math and general } \\
\text { studies marks (recoded), } 1 \text { semester, } \\
\text { grade } 4\end{array}$ & $\begin{array}{l}1 \\
\text { (worst } \\
\text { mark) }\end{array}$ & $\begin{array}{l}6 \text { (best } \\
\text { mark) }\end{array}$ & 4,47 & 0,84 \\
\hline Mark in German & $\begin{array}{l}\text { German mark (recoded) } 1 \text { semester, } \\
\text { grade } 4\end{array}$ & 1 & 6 & 4,35 & 0,93 \\
\hline $\begin{array}{l}\text { Mark in } \\
\text { mathematics }\end{array}$ & $\begin{array}{l}\text { mathematics mark (recoded), } 1 \\
\text { semester, grade } 4\end{array}$ & 1 & 6 & 4,44 & 1,00 \\
\hline $\begin{array}{l}\text { Mark in general } \\
\text { studies }\end{array}$ & $\begin{array}{l}\text { Mark in general studies (recoded) } 1 \\
\text { semester, grade } 4\end{array}$ & 1 & 6 & 4,63 & 0,96 \\
\hline \multicolumn{6}{|l|}{ Social origin } \\
\hline Social status & Highest ISEI-Score per household & 16 & 90 & 50,37 & 16,45 \\
\hline \multirow{3}{*}{$\begin{array}{l}\text { Parental education } \\
\text { (highest per } \\
\text { household) }\end{array}$} & Lower secondary education or less & 0 & 1 & 0,21 & 0,42 \\
\hline & Middle school & 0 & 1 & 0,35 & 0,48 \\
\hline & Grammar school & 0 & 1 & 0,44 & 0,50 \\
\hline $\begin{array}{l}\text { Books per } \\
\text { household }\end{array}$ & $\begin{array}{l}\text { 7-tier scale; from } 0 \text { (none) until } 7 \text { (over } \\
500 \text { ) as metric variable }\end{array}$ & 0 & 7 & 5,15 & 1,30 \\
\hline \multicolumn{6}{|l|}{ Migration } \\
\hline \multicolumn{2}{|c|}{ No immigrant background } & 0 & 1 & 0,72 & 0,41 \\
\hline \multicolumn{2}{|c|}{ Immigration background (one parent) } & 0 & 1 & 0,12 & 0,32 \\
\hline \multicolumn{2}{|c|}{ Immigration background (both parents) } & 0 & 1 & 0,16 & 0,37 \\
\hline Family language & $\begin{array}{l}\text { German language is spoken at home } \\
\text { (as well) (0), no German is spoken at } \\
\text { home (1) }\end{array}$ & 0 & 1 & 0,12 & 0,32 \\
\hline Federal state & "0“ Hessia, „1“ Bavaria & 0 & 1 & 0,66 & 0,47 \\
\hline Year of birth & Metrical & 1994 & 1998 & 1996 & 0,58 \\
\hline \multicolumn{6}{|l|}{ Competences } \\
\hline Reading skills & Total value - metrical & 1 & 26 & 17,58 & 4,72 \\
\hline Abstract reasoning & Total value - metrical & 0 & 15 & 9,84 & 2,41 \\
\hline Maths skills & Total value - metrical & 0 & 19 & 11,47 & 3,98 \\
\hline Spelling skills & Total value - metrical & 2 & 21 & 15,92 & 4,10 \\
\hline Vocabulary & Total value - metrical & 2 & 30 & 18,89 & 4,79 \\
\hline \multicolumn{6}{|l|}{$\begin{array}{l}\text { Assessment of } \\
\text { psychological } \\
\text { traits }\end{array}$} \\
\hline \multicolumn{6}{|l|}{$\begin{array}{l}\text { Students' self- } \\
\text { assessment }\end{array}$} \\
\hline $\begin{array}{l}\text { Willingness to } \\
\text { achieve }\end{array}$ & $\begin{array}{l}\text { Additive index (recoded) of }\left(, 1^{\prime \prime}=\right. \\
\text { strongly diasgree;,, } 4^{\prime \prime}=\text { strongly agree) } \\
\text { for the following statements: } \\
\text {-I prefer playing to studying } \\
\text {-when I'm studying, I don't like } \\
\text { making a big effort } \\
\text {-I don't feel like studying } \\
\text { Chrombach's Alpha: } 0,71\end{array}$ & 1 & 4 & 2,20 & 0,82 \\
\hline
\end{tabular}




\begin{tabular}{|c|c|c|c|c|c|}
\hline $\begin{array}{l}\text { Academic self- } \\
\text { concept }\end{array}$ & $\begin{array}{l}\text { Additive index (recoded) of }\left({ }^{\prime} 1^{\prime \prime}=\right. \\
\text { strongly diasgree;,, }{ }^{\prime \prime}=\text { strongly agree) } \\
\text { for the following statements: } \\
\text {-life would be so much better without } \\
\text { school } \\
\text {-I like going to school } \\
\text {-I don't enjoy learning new things } \\
\text {-School is a total bore } \\
\text { Chrombach's Alpha: } 0,86\end{array}$ & 1 & 4 & 2,85 & 0,94 \\
\hline $\begin{array}{l}\text { Motivation for } \\
\text { German }\end{array}$ & \multirow{3}{*}{$\begin{array}{l}\text { Additive index (recoded) of }\left(, 1^{\prime \prime}=\text { not }\right. \\
\text { at all; }, 5^{\prime \prime}=\text { very much) for the } \\
\text { following questions: } \\
\text { - How much do you anticipate the } \\
\text { subject }[\ldots] \\
\text { - How important is it for you to learn } \\
\text { the new topics in subject }[\ldots] \text { ? } \\
\text { - How important is it to you to be } \\
\text { knowledgeable in }[\ldots] \text { ? } \\
\text { - How strongly would you like to have } \\
\text { more time for subject }[\ldots] \text { ? } \\
\text { Chrombach's Alpha: } 0,85-0,88\end{array}$} & 1 & 5 & 3,48 & 1,09 \\
\hline $\begin{array}{l}\text { Motivation for } \\
\text { math }\end{array}$ & & 1 & 5 & 3,81 & 1,11 \\
\hline $\begin{array}{l}\text { Motivation for } \\
\text { general studies }\end{array}$ & & 1 & 5 & 3,91 & 1,07 \\
\hline \multicolumn{6}{|l|}{ Parents } \\
\hline $\begin{array}{l}\text { Conscientiousness } \\
\text { (wave 1) }\end{array}$ & $\begin{array}{l}\text { Additive index of }\left(, 1^{\prime \prime}=\text { strongly }\right. \\
\text { diasgree;,, } 5^{\prime \prime}=\text { strongly agree) for the } \\
\text { following statements: } \\
\text { - child handles material for school with } \\
\text { care } \\
\text {-child completes school tasks with } \\
\text { great dilligence } \\
\text {-child is very disciplined } \\
\text { Chrombach's Alpha: } 0,79\end{array}$ & 1 & 5 & 3,74 & 0,98 \\
\hline $\begin{array}{l}\text { Academic self- } \\
\text { concept }\end{array}$ & $\begin{array}{l}\text { Additive index of }\left({ }^{\prime \prime} 1^{\prime \prime}=\text { strongly }\right. \\
\text { diasgree;,, } 5^{\prime \prime}=\text { strongly agree) for the } \\
\text { following statements: } \\
\text { - child likes going to school } \\
\text { - child enjoys learning } \\
\text { - child has fun at school } \\
\text { Chrombach's Alpha: } 0,85\end{array}$ & 1 & 5 & 4,06 & 0,88 \\
\hline $\begin{array}{l}\text { Willingness to } \\
\text { achieve } 1\end{array}$ & $\begin{array}{l}\text { Additive index of }\left(, 1^{\prime \prime}=\text { strongly }\right. \\
\left.\text { diasgree;,, } 5^{\prime \prime}=\text { strongly agree }\right) \text { for the } \\
\text { following statement: } \\
\text { My child gets good marks if he/ she } \\
\text { makes an effort }\end{array}$ & 1 & 5 & 4,32 & 0,86 \\
\hline $\begin{array}{l}\text { Willingness to } \\
\text { achieve } 2\end{array}$ & $\begin{array}{l}\text { Additive index of }\left(, 1^{\prime \prime}=\text { strongly }\right. \\
\left.\text { diasgree;,, } 5^{\prime \prime}=\text { strongly agree }\right) \text { for the } \\
\text { following statement: } \\
\text { My child makes a real effort when the } \\
\text { homework/task is demanding }\end{array}$ & 1 & 5 & 3,70 & 1,09 \\
\hline \multicolumn{6}{|l|}{$\begin{array}{l}\text { Teachers }{ }^{\prime} \\
\text { assessment }\end{array}$} \\
\hline Work behaviour & $\begin{array}{l}\text { Additive index of }\left(, 1^{\prime \prime}=\text { strongly }\right. \\
\text { diasgree; }, 5^{\prime \prime}=\text { strongly agree) for the } \\
\text { following statements: }\end{array}$ & 1 & 5 & 3,18 & 0,86 \\
\hline
\end{tabular}




\begin{tabular}{|c|c|c|c|c|c|}
\hline & $\begin{array}{l}\text { - student gives up easily if the tasks } \\
\text { are very demanding } \\
\text { - student enjoys learning } \\
\text { - student makes a good effort when } \\
\text { tasks are demanding } \\
\text {-student actively participates during } \\
\text { class } \\
\text { Chrombach's Alpha: } 0,89\end{array}$ & & & & \\
\hline Talent (wave 1) & $\begin{array}{l}\text { Additive index of }\left(, 1^{\prime \prime}=\text { strongly }\right. \\
\left.\text { diasgree;,, } 5^{\prime \prime}=\text { strongly agree }\right) \text { for the } \\
\text { following statement: } \\
\text { - student has excellent language skills } \\
\text { - student has excellent math skills } \\
\text { - student has excellent } \\
\text { technical/ science skills } \\
\text { - student is overall talented } \\
\text { Chrombach's Alpha: } 0,90\end{array}$ & 1 & 5 & 3,30 & 0,96 \\
\hline $\begin{array}{l}\text { Parental support } \\
\text { (wave 1) }\end{array}$ & $\begin{array}{l}\text { Additive index of }\left(, 1^{\prime \prime}=\text { strongly }\right. \\
\left.\text { diasgree;,, } 5^{\prime \prime}=\text { strongly agree }\right) \text { for the } \\
\text { following statement: } \\
\text { - student is supported at home } \\
\text {-parents are very interested in the } \\
\text { students' academic development } \\
\text { - parents support student in all } \\
\text { academic respects } \\
\text { - parents are very actively involved in } \\
\text { student's school matters } \\
\text { - parents are not able to provide much } \\
\text { support regarding school matters } \\
\text { Chrombach's Alpha: } 0,90\end{array}$ & 1 & 5 & 3,74 & 1,01 \\
\hline
\end{tabular}


Table A 2: Marks in German

\begin{tabular}{|c|c|c|c|c|c|c|c|}
\hline & M1 & M2 & M3 & M4 & M5 & M6 & M7 \\
\hline \multicolumn{8}{|l|}{ Social origin } \\
\hline \multirow[t]{2}{*}{ ISEI } & $0.148^{* *}$ & $0.071^{* *}$ & $0.066^{* *}$ & $0.058^{*}$ & 0.034 & 0.024 & 0.023 \\
\hline & $(0.028)$ & $(0.022)$ & $(0.021)$ & $(0.021)$ & $(0.020)$ & $(0.020)$ & $(0.020)$ \\
\hline \multicolumn{8}{|c|}{$\begin{array}{l}\text { Parental education, reference }=\text { lower } \\
\text { secondary education }\end{array}$} \\
\hline \multirow[t]{2}{*}{ Middle school } & $0.087^{* *}$ & $0.045+$ & $0.041+$ & $0.049^{*}$ & $0.039+$ & $0.036+$ & 0.035 \\
\hline & $(0.028)$ & $(0.020)$ & $(0.020)$ & $(0.022)$ & $(0.019)$ & $(0.019)$ & $(0.019)$ \\
\hline \multirow[t]{2}{*}{ Grammar school } & $0.230^{* *}$ & $0.111^{* *}$ & $0.108^{* *}$ & $0.117^{* *}$ & $0.084^{* *}$ & $0.076^{* *}$ & $0.076^{*}$ \\
\hline & $(0.030)$ & $(0.023)$ & $(0.023)$ & $(0.023)$ & $(0.022)$ & $(0.022)$ & $(0.022)$ \\
\hline \multirow{2}{*}{$\begin{array}{l}\text { Books per } \\
\text { household }\end{array}$} & $0.095^{* *}$ & $0.038+$ & $0.038+$ & $0.040+$ & 0.025 & 0.011 & 0.011 \\
\hline & $(0.029)$ & $(0.021)$ & $(0.020)$ & $(0.022)$ & $(0.020)$ & $(0.021)$ & $(0.021)$ \\
\hline \multicolumn{8}{|l|}{ Test scores } \\
\hline \multirow[t]{2}{*}{ Reading skills } & & $0.147^{* *}$ & $0.141^{* *}$ & $0.134^{* *}$ & $0.089^{* *}$ & $0.096^{* *}$ & $0.096^{* *}$ \\
\hline & & $(0.021)$ & $(0.021)$ & $(0.021)$ & $(0.018)$ & $(0.018)$ & $(0.018)$ \\
\hline \multirow[t]{2}{*}{ Spelling skills } & & $0.317^{* *}$ & $0.293^{* *}$ & $0.256^{* *}$ & $0.203^{* *}$ & $0.198^{* *}$ & $0.199^{* *}$ \\
\hline & & $(0.020)$ & $(0.021)$ & $(0.022)$ & $(0.022)$ & $(0.022)$ & $(0.023)$ \\
\hline \multirow[t]{2}{*}{ Vocabulary } & & $0.133^{* *}$ & $0.136^{* *}$ & $0.130^{* *}$ & $0.086^{* *}$ & $0.089^{* *}$ & $0.089^{* *}$ \\
\hline & & $(0.021)$ & $(0.021)$ & $(0.020)$ & $(0.021)$ & $(0.021)$ & $(0.021)$ \\
\hline \multirow[t]{2}{*}{ Maths skills } & & $0.151^{* *}$ & $0.153^{* *}$ & $0.122^{* *}$ & 0.039 & 0.037 & 0.037 \\
\hline & & $(0.018)$ & $(0.018)$ & $(0.018)$ & $(0.022)$ & $(0.022)$ & $(0.022)$ \\
\hline \multirow[t]{2}{*}{ Abstract reasoning } & & 0.007 & 0.016 & 0.014 & -0.015 & -0.012 & -0.012 \\
\hline & & $(0.017)$ & $(0.017)$ & $(0.017)$ & $(0.015)$ & $(0.015)$ & $(0.015)$ \\
\hline \multicolumn{8}{|c|}{ Students' self-assessment } \\
\hline \multirow[t]{2}{*}{$\begin{array}{l}\text { Academic self- } \\
\text { concept }\end{array}$} & & & 0.036 & 0.028 & -0.005 & -0.004 & -0.003 \\
\hline & & & $(0.030)$ & $(0.030)$ & $(0.027)$ & $(0.027)$ & $(0.028)$ \\
\hline \multirow[t]{2}{*}{$\begin{array}{l}\text { Willingness to } \\
\text { achieve }\end{array}$} & & & 0.024 & 0.045 & 0.032 & 0.037 & 0.038 \\
\hline & & & $(0.030)$ & $(0.029)$ & $(0.027)$ & $(0.027)$ & $(0.027)$ \\
\hline \multirow[t]{2}{*}{$\begin{array}{l}\text { Motivation for } \\
\text { German }\end{array}$} & & & $0.074^{* *}$ & $0.063^{* *}$ & $0.066^{* *}$ & $0.061^{* *}$ & $0.061^{* *}$ \\
\hline & & & $(0.018)$ & $(0.018)$ & $(0.017)$ & $(0.017)$ & $(0.017)$ \\
\hline \multicolumn{8}{|l|}{ Parental assessment } \\
\hline \multirow[t]{2}{*}{ Conscientiousness } & & & & $0.072^{* *}$ & $0.043+$ & 0.034 & 0.034 \\
\hline & & & & $(0.021)$ & $(0.021)$ & $(0.020)$ & $(0.020)$ \\
\hline \multirow{2}{*}{$\begin{array}{l}\text { Academic self- } \\
\text { concept }\end{array}$} & & & & 0.034 & 0.009 & 0.001 & 0.001 \\
\hline & & & & $(0.023)$ & $(0.019)$ & $(0.017)$ & $(0.017)$ \\
\hline \multirow{2}{*}{$\begin{array}{l}\text { Willingness to } \\
\text { achieve } 1\end{array}$} & & & & $0.091^{* *}$ & $0.059^{*}$ & $0.063^{*}$ & $0.063^{*}$ \\
\hline & & & & $(0.021)$ & $(0.021)$ & $(0.020)$ & $(0.020)$ \\
\hline \multirow{2}{*}{$\begin{array}{l}\text { Willingness to } \\
\text { achieve } 2\end{array}$} & & & & 0.035 & 0.004 & 0.006 & 0.006 \\
\hline & & & & $(0.020)$ & $(0.017)$ & $(0.017)$ & $(0.017)$ \\
\hline \multicolumn{8}{|c|}{ Teachers' assessment } \\
\hline \multirow[t]{2}{*}{ Talent } & & & & & $0.237^{* *}$ & $0.200^{* *}$ & $0.199^{* *}$ \\
\hline & & & & & $(0.055)$ & $(0.053)$ & $(0.053)$ \\
\hline Work behaviour & & & & & $0.312+$ & $0.298+$ & $0.298+$ \\
\hline & & & & & $(0.134)$ & $(0.138)$ & $(0.138)$ \\
\hline Parental support & & & & & & $0.117^{*}$ & $0.105+$ \\
\hline & & & & & & $(0.036)$ & $(0.045)$ \\
\hline
\end{tabular}




\begin{tabular}{|l|c|c|c|c|c|c|c|}
\hline $\begin{array}{l}\text { Federal state } \\
\text { Bavaria, reference= } \\
\text { Hessia }\end{array}$ & -0.078 & $\mathbf{- 0 . 2 8 2}$ & $\mathbf{- 0 . 2 6 8 ^ { * }}$ & $\mathbf{- 0 . 2 5 4 ^ { * }}$ & $\mathbf{- 0 . 1 6 4 +}$ & $\mathbf{- 0 . 1 5 0 +}$ & $\mathbf{- 0 . 1 5 3 +}$ \\
\cline { 2 - 9 } & $(0.101)$ & $(0.106)$ & $(0.105)$ & $(0.105)$ & $(0.078)$ & $(0.079)$ & $(0.079)$ \\
\hline $\begin{array}{l}\text { Interaction parental } \\
\text { support X federal } \\
\text { state }\end{array}$ & & & & & & & 0.022 \\
\hline Intercept & 4.369 & 4.500 & 4.232 & 4.256 & 4.183 & 4.189 & 4.191 \\
\hline & $0.056)$ & $(0.064)$ & $(0.092)$ & $(0.092)$ & $(0.079)$ & $(0.078)$ & $(0.077)$ \\
\hline $\begin{array}{l}\text { Variance on school } \\
\text { level }\end{array}$ & 0,038 & 0,086 & 0,085 & 0,074 & 0,043 & 0,042 & 0,041 \\
\hline & $(0,446)$ & $(0,227)$ & $(0,228)$ & $(0,243)$ & $(0,203)$ & $(0,207)$ & $(0,207)$ \\
\hline $\begin{array}{l}\text { Variance on } \\
\text { individual level }\end{array}$ & 0,629 & 0,355 & 0,349 & 0,332 & 0,271 & 0,264 & 0,264 \\
\hline & $0.025)$ & $(0.035)$ & $(0.035)$ & $(0.037)$ & $(0.034)$ & $(0.034)$ & $(0.034)$ \\
\hline Observations & 2032 & 2032 & 2032 & 2032 & 2032 & 2032 & 2032 \\
\hline
\end{tabular}

$+\mathrm{p}<0.10,{ }^{*} \mathrm{p}<0.05,{ }^{* *} \mathrm{p}<0.01$; Immigrant background, family language, year of birth, gender and federal states were controlled for in each model 
Table A 3: Marks in Maths

\begin{tabular}{|c|c|c|c|c|c|c|c|}
\hline & M1 & M2 & M3 & M4 & M5 & M6 & M7 \\
\hline \multicolumn{8}{|l|}{ Social origin } \\
\hline \multirow[t]{2}{*}{ ISEI } & $0.133^{* *}$ & $0.051+$ & 0.046 & 0.036 & 0.006 & 0.004 & 0.003 \\
\hline & $(0.031)$ & $(0.026)$ & $(0.025)$ & $(0.026)$ & $(0.021)$ & $(0.022)$ & $(0.022)$ \\
\hline \multicolumn{8}{|c|}{$\begin{array}{l}\text { Parental education, reference=lower } \\
\text { secondary education }\end{array}$} \\
\hline \multirow[t]{2}{*}{ Middle school } & $0.096^{*}$ & 0.031 & 0.032 & 0.040 & 0.026 & 0.025 & 0.023 \\
\hline & $(0.032)$ & $(0.025)$ & $(0.024)$ & $(0.026)$ & $(0.022)$ & $(0.022)$ & $(0.023)$ \\
\hline \multirow[t]{2}{*}{ Grammar school } & $0.197^{* *}$ & $0.057+$ & $0.066^{*}$ & $0.076^{*}$ & 0.032 & 0.030 & 0.030 \\
\hline & $(0.037)$ & $(0.029)$ & $(0.029)$ & $(0.029)$ & $(0.025)$ & $(0.025)$ & $(0.025)$ \\
\hline \multirow{2}{*}{$\begin{array}{l}\text { Books per } \\
\text { household }\end{array}$} & $0.116^{* *}$ & $0.059+$ & $0.060^{*}$ & $0.062^{*}$ & $0.046+$ & 0.043 & 0.043 \\
\hline & $(0.033)$ & $(0.027)$ & $(0.026)$ & $(0.027)$ & $(0.022)$ & $(0.023)$ & $(0.023)$ \\
\hline \multicolumn{8}{|l|}{ Test scores } \\
\hline \multirow[t]{2}{*}{ Reading skills } & & $0.084^{*}$ & $0.093^{*}$ & $0.079 *$ & 0.025 & 0.026 & 0.027 \\
\hline & & $(0.030)$ & $(0.029)$ & $(0.029)$ & $(0.023)$ & $(0.022)$ & $(0.023)$ \\
\hline \multirow[t]{2}{*}{ Spelling skills } & & $0.147^{* *}$ & $0.161^{* *}$ & $0.119^{* *}$ & $0.051+$ & $0.049+$ & $0.050+$ \\
\hline & & $(0.025)$ & $(0.025)$ & $(0.026)$ & $(0.022)$ & $(0.022)$ & $(0.022)$ \\
\hline \multirow[t]{2}{*}{ Vocabulary } & & $0.098^{* *}$ & $0.102^{* *}$ & $0.092 * *$ & 0.039 & 0.040 & 0.040 \\
\hline & & $(0.025)$ & $(0.025)$ & $(0.025)$ & $(0.023)$ & $(0.024)$ & $(0.024)$ \\
\hline \multirow[t]{2}{*}{ Maths skills } & & $0.389^{* *}$ & $0.321^{* *}$ & $0.289^{* *}$ & $0.190^{* *}$ & $0.190^{* *}$ & $0.190^{* *}$ \\
\hline & & $(0.022)$ & $(0.023)$ & $(0.023)$ & $(0.028)$ & $(0.028)$ & $(0.028)$ \\
\hline \multirow[t]{2}{*}{ Abstract reasoning } & & $0.139^{* *}$ & $0.125^{* *}$ & $0.125^{* *}$ & $0.092^{* *}$ & $0.093^{* *}$ & $0.093^{* *}$ \\
\hline & & $(0.021)$ & $(0.020)$ & $(0.019)$ & $(0.017)$ & $(0.017)$ & $(0.017)$ \\
\hline \multicolumn{8}{|c|}{ Student's self-assessment } \\
\hline \multirow[t]{2}{*}{$\begin{array}{l}\text { Academic self- } \\
\text { concept }\end{array}$} & & & -0.036 & -0.046 & $-0.080^{*}$ & $-0.080^{*}$ & $-0.079^{*}$ \\
\hline & & & $(0.033)$ & $(0.033)$ & $(0.032)$ & $(0.032)$ & $(0.032)$ \\
\hline \multirow{2}{*}{$\begin{array}{l}\text { Willingness to } \\
\text { achieve }\end{array}$} & & & 0.011 & 0.036 & 0.017 & 0.018 & 0.020 \\
\hline & & & $(0.033)$ & $(0.032)$ & $(0.029)$ & $(0.029)$ & $(0.029)$ \\
\hline \multirow{2}{*}{$\begin{array}{l}\text { Motivation for } \\
\text { Maths }\end{array}$} & & & $0.173^{* *}$ & $0.156^{* *}$ & $0.132^{* *}$ & $0.132^{* *}$ & $0.132^{* *}$ \\
\hline & & & $(0.018)$ & $(0.018)$ & $(0.016)$ & $(0.016)$ & $(0.016)$ \\
\hline \multicolumn{8}{|l|}{ Parental assessment } \\
\hline \multirow[t]{2}{*}{ Conscientiousness } & & & & $0.053+$ & 0.017 & 0.014 & 0.014 \\
\hline & & & & $(0.024)$ & $(0.019)$ & $(0.019)$ & $(0.019)$ \\
\hline \multirow{2}{*}{$\begin{array}{l}\text { Academic self- } \\
\text { concept }\end{array}$} & & & & 0.046 & 0.017 & 0.015 & 0.015 \\
\hline & & & & $(0.033)$ & $(0.025)$ & $(0.025)$ & $(0.025)$ \\
\hline \multirow{2}{*}{$\begin{array}{l}\text { Willingness to } \\
\text { achieve } 1\end{array}$} & & & & $0.092^{* *}$ & $0.056^{*}$ & $0.056^{*}$ & $0.056^{*}$ \\
\hline & & & & $(0.023)$ & $(0.021)$ & $(0.021)$ & $(0.021)$ \\
\hline \multirow{2}{*}{$\begin{array}{l}\text { Willingness to } \\
\text { achieve } 2\end{array}$} & & & & $0.096^{* *}$ & $0.058^{*}$ & $0.058^{*}$ & $0.058^{*}$ \\
\hline & & & & $(0.025)$ & $(0.023)$ & $(0.023)$ & $(0.022)$ \\
\hline \multicolumn{8}{|c|}{ Teachers' assessment } \\
\hline Talent & & & & & $0.264^{* *}$ & $0.255^{* *}$ & $0.253^{* *}$ \\
\hline & & & & & $(0.062)$ & $(0.060)$ & $(0.060)$ \\
\hline Work behaviour & & & & & $0.445+$ & $0.441+$ & $0.441+$ \\
\hline & & & & & $(0.187)$ & $(0.187)$ & $(0.187)$ \\
\hline Parental support & & & & & & 0.031 & 0.009 \\
\hline & & & & & & $(0.032)$ & $(0.035)$ \\
\hline Federal state & 0.099 & -0.122 & -0.109 & -0.088 & 0.005 & 0.009 & 0.004 \\
\hline
\end{tabular}




\begin{tabular}{|l|l|l|l|l|l|l|l|}
\hline Bavaria Ref. Hessia & $(0.140)$ & $(0.142)$ & $(0.140)$ & $(0.139)$ & $(0.089)$ & $(0.090)$ & $(0.090)$ \\
\hline $\begin{array}{l}\text { Interaction parental } \\
\text { support X federal } \\
\text { state }\end{array}$ & & & & & & & 0.041 \\
\cline { 2 - 9 } & 4.337 & 4.478 & 3.811 & 3.850 & 3.868 & 3.865 & 3.868 \\
\hline Intercept & $(0.071)$ & $(0.079)$ & $(0.103)$ & $(0.099)$ & $(0.081)$ & $(0.080)$ & $(0.080)$ \\
\hline $\begin{array}{l}\text { Variance on school } \\
\text { level }\end{array}$ & 0,083 & 0,143 & 0,132 & 0,116 & 0,060 & 0,059 & 0,058 \\
\hline & $(0,367)$ & $(0,238)$ & $(0,249)$ & $(0,275)$ & $(0,242)$ & $(0,248)$ & $(0,250)$ \\
\hline $\begin{array}{l}\text { Variance on } \\
\text { individual level }\end{array}$ & 0,837 & 0,508 & 0,482 & 0,457 & 0,358 & 0,358 & 0,358 \\
\hline Observations & $(0.033)$ & $(0.051)$ & $(0.053)$ & $(0.056)$ & $(0.036)$ & $(0.036)$ & $(0.036)$ \\
\hline
\end{tabular}

$+\mathrm{p}<0.10,{ }^{*} \mathrm{p}<0.05,{ }^{* *} \mathrm{p}<0.01$; Immigrant background, family language, year of birth, gender and federal states were controlled for in each model 
Table A 4: Marks in general studies

\begin{tabular}{|c|c|c|c|c|c|c|c|}
\hline & M1 & M2 & M3 & M4 & M5 & M6 & M7 \\
\hline \multicolumn{8}{|l|}{ Social origin } \\
\hline \multirow[t]{2}{*}{ ISEI } & $0.153^{* *}$ & $0.089^{* *}$ & $0.080^{*}$ & $0.072^{*}$ & $0.044+$ & 0.034 & 0.032 \\
\hline & $(0.030)$ & $(0.027)$ & $(0.026)$ & $(0.027)$ & $(0.022)$ & $(0.022)$ & $(0.022)$ \\
\hline \multicolumn{8}{|l|}{$\begin{array}{l}\text { Parental education, } \\
\text { reference= lower } \\
\text { secondary } \\
\text { education }\end{array}$} \\
\hline \multirow[t]{2}{*}{ Middle school } & $0.086^{*}$ & 0.042 & 0.041 & 0.047 & 0.037 & 0.033 & 0.029 \\
\hline & $(0.033)$ & $(0.027)$ & $(0.025)$ & $(0.026)$ & $(0.022)$ & $(0.022)$ & $(0.022)$ \\
\hline \multirow[t]{2}{*}{ Grammar school } & $0.184^{* *}$ & $0.081^{*}$ & $0.070^{*}$ & $0.079 *$ & 0.043 & 0.035 & 0.034 \\
\hline & $(0.037)$ & $(0.032)$ & $(0.029)$ & $(0.030)$ & $(0.027)$ & $(0.027)$ & $(0.027)$ \\
\hline \multirow[t]{2}{*}{$\begin{array}{l}\text { Books per } \\
\text { household }\end{array}$} & $0.090^{*}$ & 0.043 & 0.030 & 0.035 & 0.023 & 0.009 & 0.010 \\
\hline & $(0.029)$ & $(0.026)$ & $(0.025)$ & $(0.027)$ & $(0.022)$ & $(0.022)$ & $(0.022)$ \\
\hline \multicolumn{8}{|l|}{ Test scores } \\
\hline \multirow[t]{2}{*}{ Reading skills } & & $0.091^{*}$ & $0.091^{*}$ & $0.084^{*}$ & 0.035 & $0.043+$ & $0.043+$ \\
\hline & & $(0.031)$ & $(0.030)$ & $(0.030)$ & $(0.022)$ & $(0.022)$ & $(0.022)$ \\
\hline \multirow[t]{2}{*}{ Spelling skills } & & $0.180^{* *}$ & $0.173^{* *}$ & $0.133^{* *}$ & $0.076^{* *}$ & $0.069^{*}$ & $0.070^{*}$ \\
\hline & & $(0.026)$ & $(0.026)$ & $(0.027)$ & $(0.022)$ & $(0.022)$ & $(0.022)$ \\
\hline \multirow[t]{2}{*}{ Vocabulary } & & $0.127^{* *}$ & $0.110^{* *}$ & $0.107^{* *}$ & $0.067^{*}$ & $0.070^{*}$ & $0.071^{*}$ \\
\hline & & $(0.027)$ & $(0.027)$ & $(0.027)$ & $(0.023)$ & $(0.023)$ & $(0.023)$ \\
\hline \multirow[t]{2}{*}{ Maths skills } & & $0.187^{* *}$ & $0.171^{* *}$ & $0.143^{* *}$ & $0.048+$ & 0.047 & $0.047+$ \\
\hline & & $(0.022)$ & $(0.022)$ & $(0.021)$ & $(0.025)$ & $(0.025)$ & $(0.025)$ \\
\hline \multirow[t]{2}{*}{ Abstract reasoning } & & $0.058^{*}$ & $0.064^{*}$ & $0.064^{*}$ & $0.035+$ & $0.039+$ & $0.040^{*}$ \\
\hline & & $(0.020)$ & $(0.020)$ & $(0.020)$ & $(0.017)$ & $(0.017)$ & $(0.017)$ \\
\hline \multicolumn{8}{|c|}{ Student's self-assessment } \\
\hline \multirow{2}{*}{$\begin{array}{l}\text { Academic self- } \\
\text { concept }\end{array}$} & & & 0.041 & 0.020 & -0.015 & -0.014 & -0.012 \\
\hline & & & $(0.033)$ & $(0.033)$ & $(0.032)$ & $(0.032)$ & $(0.032)$ \\
\hline \multirow[t]{2}{*}{$\begin{array}{l}\text { Willingness to } \\
\text { achieve }\end{array}$} & & & -0.030 & -0.010 & -0.024 & -0.018 & -0.016 \\
\hline & & & $(0.033)$ & $(0.032)$ & $(0.029)$ & $(0.028)$ & $(0.028)$ \\
\hline \multirow{2}{*}{$\begin{array}{l}\text { Motivation for } \\
\text { general studies }\end{array}$} & & & $0.171^{* *}$ & $0.162^{* *}$ & $0.146^{* *}$ & $0.142^{* *}$ & $0.139^{* *}$ \\
\hline & & & $(0.021)$ & $(0.020)$ & $(0.018)$ & $(0.017)$ & $(0.017)$ \\
\hline \multicolumn{8}{|l|}{ Parental assessment } \\
\hline \multirow[t]{2}{*}{ Conscientiousness } & & & & $0.083^{* *}$ & $0.047^{*}$ & 0.036 & 0.037 \\
\hline & & & & $(0.023)$ & $(0.020)$ & $(0.021)$ & $(0.021)$ \\
\hline \multirow{2}{*}{$\begin{array}{l}\text { Academic self- } \\
\text { concept }\end{array}$} & & & & $0.066^{*}$ & 0.040 & 0.032 & 0.032 \\
\hline & & & & $(0.027)$ & $(0.022)$ & $(0.022)$ & $(0.022)$ \\
\hline \multirow{2}{*}{$\begin{array}{l}\text { Willingness to } \\
\text { achieve } 1\end{array}$} & & & & $0.066^{*}$ & $0.036+$ & $0.040+$ & $0.040+$ \\
\hline & & & & $(0.020)$ & $(0.019)$ & $(0.018)$ & $(0.018)$ \\
\hline \multirow{2}{*}{$\begin{array}{l}\text { Willingness to } \\
\text { achieve } 2\end{array}$} & & & & 0.018 & -0.017 & -0.014 & -0.016 \\
\hline & & & & $(0.025)$ & $(0.021)$ & $(0.021)$ & $(0.021)$ \\
\hline \multicolumn{8}{|c|}{ Teachers' assessment } \\
\hline \multirow[t]{2}{*}{ Talent } & & & & & $0.206^{* *}$ & $0.167^{* *}$ & $0.162^{* *}$ \\
\hline & & & & & $(0.041)$ & $(0.038)$ & $(0.039)$ \\
\hline Work behaviour & & & & & $0.448^{* *}$ & $0.435^{* *}$ & $0.433^{* *}$ \\
\hline & & & & & $(0.123)$ & $(0.127)$ & $(0.128)$ \\
\hline Parental support & & & & & & $0.123^{* *}$ & 0.071 \\
\hline & & & & & & $(0.036)$ & $(0.038)$ \\
\hline
\end{tabular}




\begin{tabular}{|l|l|l|l|l|l|l|l|}
\hline $\begin{array}{l}\text { Federal state } \\
\text { Bavaria, reference= } \\
\text { Hessia }\end{array}$ & -0.124 & $\mathbf{- 0 . 2 9 0 +}$ & $\mathbf{- 0 . 2 6 4 +}$ & -0.252 & $\mathbf{- 0 . 1 5 8 +}$ & -0.143 & $\mathbf{- 0 . 1 5 4 +}$ \\
\hline $\begin{array}{l}\text { Interaction Parental } \\
\text { support X federal } \\
\text { state }\end{array}$ & $(0.140)$ & $(0.136)$ & $(0.137)$ & $(0.140)$ & $(0.081)$ & $(0.080)$ & $(0.079)$ \\
\hline Intercept & & & & & & & \\
\hline & 4.663 & 4.770 & 4.084 & 4.101 & 4.099 & 4.103 & 4.123 \\
\hline $\begin{array}{l}\text { Variance on school } \\
\text { level }\end{array}$ & $(0.069)$ & $(0.074)$ & $(0.111)$ & $(0.109)$ & $(0.088)$ & $(0.084)$ & $(0.085)$ \\
\hline & 0,086 & 0,115 & 0,115 & 0,101 & 0,053 & 0,049 & 0,048 \\
\hline $\begin{array}{l}\text { Variance on } \\
\text { individual level }\end{array}$ & $0,687)$ & $(0,275)$ & $(0,271)$ & $(0,292)$ & $(0,149)$ & $(0,161)$ & $(0,160)$ \\
\hline Observations & $(0.046)$ & $(0.060)$ & $(0.063)$ & $(0.065)$ & $(0.025)$ & $(0.025)$ & $(0.025)$ \\
\hline
\end{tabular}

$+\mathrm{p}<0.10,{ }^{*} \mathrm{p}<0.05,{ }^{* *} \mathrm{p}<0.01$; Immigrant background, family language, year of birth, gender and federal states were controlled for in each model 